\title{
A European Fleet to address the Migration Challenge in the Mediterranean? The EUNAVFOR MED/Sophia between Lights and Shadows
}

\author{
By Gian Lorenzo Zichi*
}

\begin{abstract}
The migration crisis involving Europe is a many-sided phenomenon, from the beginning causing significant security challenges for all the countries and international organizations concerned. At the centre of this problem, the migratory routes through the Mediterranean Sea appear to be of peculiar relevance because of the increasing number of illegal trafficking in human beings and alleged terrorism suspects arriving in an uncontrolled way to Europe. As facts have subsequently shown, the European Union (EU) was not prepared to meet this challenge, either on the humanitarian or the security side. Nevertheless, ever since its first attempt to give a common response to the migration emergency - through the Agenda signed in May 2015 - the EU was aware that tackling security threats in the Mediterranean waters would be an essential part of the problem. Weeks after, a European Union Mediterranean Naval Force (EUNAVFOR MED) was thus launched, with specific objectives. As a military operation, on one side it was devoted to improving 'search and rescue actions' at sea; on the other, it would try to contrast the traffickers' illegal business in human beings, patrolling the area. This paper-following an international history perspective and with its specific research methodology - intends to provide an overview of the activity of the Operation Sophia with its potentials and limits. Moreover, the analysis aims at defining the political design at the base of a mission, its weak and contradictory mandate, its operational but also political role, underlining how even a pragmatic instrument like a military operation cannot be left alone to provide security, but needs to play a specific role within the framework of a more comprehensive migration strategy by the European Union to prove itself effective and not a mere corollary.
\end{abstract}

Keywords: Migration, Security, European Union, EUNAVFOR MED/Sophia

\section{Introduction}

The recent migration challenge poses a series of concerns for Mediterranean and European security and stability. The increase of sea flows registered since 2013 (United Nations High Commissioner for Refugees [UNHCR] 2013), now evolved into a structural phenomenon, saw the Union react with delay and without a full understanding of the real dimension of the emergency. This was partially due to its contemporary engagement in other security issues - like the threat of terrorist attacks and the fight against ISIL (European Council [EC] 2015a, Nilsson 2017). From the beginning, one of the main aspects was that this new challenge had a maritime dimension. All the main routes directed to Europe the Western, Central and Eastern Mediterranean - passed through the basin

${ }^{*} \mathrm{PhD}$ Student, University of Cagliari, Italy. 
(Frontex 2018), which had also become a theatre both of illegal business committed to the trafficking of human beings and of deadly accidents for thousands of migrants. These problems have directly involved the Southern Members of the Union as natural countries of reception, particularly Greece and Italy, that started to bear the burden of an increased number of arrivals on their coasts, especially during the peak phase between 2014 and 2016 (Ritter et al 2017). In 2015, almost $80 \%$ of the 800.000 migrants who arrived in the continent passed through the Aegean Sea and Greece (UNHCR 2015a), while in 2016 Italy recorded 181.436 arrivals through the Central Mediterranean route (IOM 2017). In such a complex context, still characterized by the absence of a comprehensive and general approach by the EU, the Mediterranean Border States started to outline their own strategies to address the most serious aspects of this asymmetric emergency. However, all the answers lacked a broad perspective, as they were focused on those aspects representing a direct threat to their national security; thus, the general priority was the reduction of the flows and the incidents in the Mediterranean. Also for this reason, the first answers were related to the maritime dimension.

Between the summer and the autumn of 2013, Italy was the first to theorize a naval operation, guided by its Navy, to address the most vicious aspects of the phenomenon, in particular to save lives at sea and to fight the traffickers in the Mediterranean Sea. In October the Mare Nostrum Operation officially started; in its ten months of activities some lights and many shadows would emerge, as will be explained later. Above all, the usefulness of the naval operations as a tool capable of helping the management of the emergency at sea was recognized also by supranational organizations, at both the European institutional level - with the launch of the Triton Operation in the autumn of 2014, in substitution of the expire Italian mission, and the Atlantic Alliance level, with the regional mission Sea Guardian Operation organized by the NATO on July 2016.

Among the panoply of maritime initiatives, the aim of this paper is to outline the activity of the main military operation led by the EU, known as the European Union Naval Force Mediterranean (EUNAVFOR MED), which was established in May 2015, put under Italian command and is still ongoing (European Union External Action [EEAS] 2016a). This operation deserves attention for its particular nature and for the timing when it was launched. The EUNAVFOR MED - since autumn 2015 renamed Sophia Operation - represents a European naval military mission that involves almost all Member States and can be considered an important step of the migratory answer but also an expression of European cooperation on the defence field. It was approved during the dramatic spring weeks when the number of deadly tragedies in the Mediterranean had reached dramatic levels. In this context, while the Union started to better define its migratory strategy with the presentation of the Agenda on Migration, the need also emerged for an instrument capable of answering the most urgent and critical aspects of the flows. To react to these challenges, the European military operation was born with two purposes: to fight the illegal routes of human traffickers and to destroy smugglers' boats and train Libyan 
coastguards (Hermanin 2017).

Another main goal that this paper aims to achieve is to briefly define the scenario in which the theorization of the EUNAVFOR MED was made possible, and then to try to reconstruct its original mandate and how the mission worked in three years of activity. This appears to be significant to determine which of these naval missions could be useful to manage the migratory phenomenon, and in particular which contribution Operation Sophia effectively gave to the management of the present situation, when it seems that the "crisis of the extremely high figure of 2015 and 2016 has been overcome», as said in January 2018 by the German Interior Minister Thomas de Maizére (Chase 2018). The last part of the paper will investigate the light and shadows raised by the operation; if the mission disregarded the original expectations and mandate; the real contribution in the current decrease of flows to Europe; and finally, if a military instrument can fill the political gap left by national states and European institutions on the field of migration or, without a comprehensive strategy and a shared political coverage, a military tool could risk remaining in an uncertain operative stage.

\section{State of Art and Methodology}

Due to the contemporaneity of the mission, there still are only a few publications on this subject. Among the most significant works is the book edited by Marianne Riddervord in 2018 entitled The Maritime Turn in EU Foreign and Security Policies: Aims, Actors and Mechanisms of Integration, in which the author dedicates a specific chapter on the mission named 'The EU Naval Mission Sophia: A Humanitarian Operation to Help Refugees in Distress at Sea?', that offers a useful overview of the activity and significant of the EU initiative. Another important essay, which appeared in 2016, is L'approche globale à la croisée des champs de la sécurité européenne, edited by Chantal Lavallée and Florent Pouponneau, that tries to contextualize this operation in the general European approach to migration. Other reflections are available in the form of working papers, like that of Anne Ingemann Johansen entitled Assessing the European Union's strategic capacity: the case of EUNAVFOR MED Operation Sophia, and published in July 2017 by the journal European Security.

Along with this specific literature, the present paper was mainly based on official documents and notes created by European Union Institutions for the reconstruction of the activities of the first two years - until January 2017 have been used the declassified document draw up by the EUNAVFOR MED Command and sent to the Political and Security Committee of the EU. This methodological decision was made in accordance with the specific approach of the history of international relations, in the attempt to suggest an analysis on the subject starting from the first source materials. 


\section{The Migration Emergency towards Europe: A Challenge from the Sea and the Background of the Operation}

As previously said, some of the most critical humanitarian and security problems related to the migration appeared in the basin even before the emergency situation of 2015. From 2011 to 2013, an inflow from the sea was registered in the coastal states of Southern Europe, in particular Greece and Italy. This was fostered by the political upheavals in the MENA (Middle East and North Africa) area in the aftermaths of the Arab Springs and the surge of the Syrian Civil War (Park 2015, Grant and Domokol 2011, Faath and Mattes 2014). In 2013 Greece saw the number of migrants arriving on its shores triple: from 3.600 in 2012 to 11.400 (UNHCR 2015b), and in the summer of the same year Rome also registered a huge increase in the incoming flows (Warnes 2014, Chalabi 2013), with a record of 8.932 rescued in six weeks between July and October. In other words, $75 \%$ of the annual arrivals gathered in four months (Chope 2013). In comparison with the previous year, the number of arrivals in Italy in 2013 had quadrupled: from 10. 379 to 40.304 (FRONTEX 2014).

In order to react to this humanitarian emergency, but also to quiet the domestic political and social anxieties, the Italian government was the first to arrange, in the autumn of 2013, a large-scale, national naval operation in the Mediterranean guided by the Navy. On October 18, 2013 the Mare Nostrum Operation was thus officially launched thought as a «military and humanitarian operation aimed at tackling the humanitarian emergency in the Strait of Sicily, due to the dramatic increase in migration flows» (Marina Militare 2014). The Italian initiative was at first praised as an important humanitarian action, capable of rescuing over 160.000 migrants at sea, with an average of 400 per day during its ten months of activity (Bajekal 2014, Gauci 2016). However, the operation has also attracted ferocious criticism - in particular from the British government - and it was accused of representing a pull factor and thus increasing illegal migration (Crawley et al. 2018). Anyway, after less than a year in which Mare Nostrum saved more than 150.000 people at sea (UNHCR 2014), Rome announced on 9 October through the Interior Minister Angelino Alfano, its intention to interrupt the mission, mainly due to the high costs of management, that had reached more than $€ 9 \mathrm{~m}$ a month for a total of $€ 114 \mathrm{~m}$ (Ministero dell'Interno 2014). The retreat of the mission was not inspired by the end of the emergency. In fact, Italy in 2014 was also affected by a record number of 170.000 migrant arrivals by sea, something that led the Italian institutions to request a shared commitment in the Mediterranean from the EU (IOM 2015). The result of this claim was the launch of the Triton Operation by the Union through the Frontex agency, by Rome, that substituted Mare Nostrum but seemed particularly different. In fact, the Triton Operation - in which 26 Member States took part - was more a borders control mission, with a range of activity more narrow to the Italian shores and with a substantially lower budget of $€ 2.9$ per month (Riddervold 2018). 
The shifting from the Italian operation to the European one was accompanied by the persistence of the emergency and an increase of fatalities in the Mediterranean, which in the first four months of 2015 reached 1710 (IOM 2018). These daily tragedies at sea represented a strong stimulus for the EU institutions to reconsider with new attention the maritime dimension of this political and humanitarian emergency. It was indeed a sort of logical consequence that the turning point of this new mood was represented by one of the deadliest tragedies in the Mediterranean, which happened on April $18^{\text {th }}$ and caused more than 800 migrants to lose their lives (Kirchgaessner and Bonomolo 2015). Following this event, a joint meeting of the Foreign and Interior Ministers was held on April $20^{\text {th }}$ in Luxemburg, chaired by High Representative of the Union for Foreign Affairs and Security Policy (HR) Federica Mogherini, in which the Migration, Home Affairs and Citizenship Commissioner Avramopoulos presented the «Ten points action plan on migration». The second of them prefigured the creation of "a systematic effort to capture and destroy vessels used by the smugglers», through «the positive results obtained with the Atalanta ${ }^{\dagger}$ operation should inspire us to similar operations against smugglers in the Mediterranean» (EC 2015b): this was a first opening to the possibility of creating a naval military operation as a useful instrument to manage the migration flows in the basin. A concrete position by the EU on the opportunity to launch a specific mission in the Mediterranean waters was taken within the special meeting of the European Council 23 April 2015. In this occasion, the Council invited the High Representative «to immediately begin preparations for a possible Common Security and Defence Policy (CSDP) operation» (EC 2015c). The European Commission and the Political and Security Committee (PSC), after received the mandate by the Council, started to design the basis for the military operation as part of a political strategy that in those weeks was about to be presented. The European approach on migration was finally announced by the Commission on May $13^{\text {th }}$ through the Agenda on Migration, which represents the first cornerstone of a coherent European policy on the matter. Here the attention for the Mediterranean clearly emerged. Under the framework of the Agenda, the Commission established to «triple the budget for the Frontex joint-operations Triton and Poseidon», in order to «saving lives at sea» and to «targeting criminal smuggling networks» (European Commission 2015). Even without any explicit reference to specific military operation, these measures represent the political coverage under which would have been a further practical and operative action possible- as military-naval operations. It is also important to note how, since this moment, the Commission believed in the opportunity to deal with this challenge through a double approach: one based on specific search and rescue (SAR) operations and fighting the traffickers at sea; the other based on internal cooperation among the European States under the relocation quota system.

However, this design was partially changed by the growing emergency of the arrivals and by the first criticisms by some Member States related to the

\footnotetext{
${ }^{\dagger}$ The European Union Naval Force (Op Atalanta) Somalia - Operation Atalanta was launched on 8 December 2008 and it is the main European attempt in order to fight the illegal business of the piracy in the Horn of Africa. See also at: http://eunavfor.eu/.
} 
Agenda, in particular on the mandatory quota system of relocation (Hammond 2015, Dobrescu et al. 2017).

With the Commission threatened on its design, between the end of April and mid-May, the EU Council took the initiative to realize the easiest part of the European strategy on migration, i.e. to establish a maritime military operation. It is also important to underline that if a supposed mission received a general unanimous consensus among the Member States, outside the Union it raised some criticism. First of all, the United Nations expressed some perplexities about this mission for its possible collateral damages, as stated by the UN's special envoy on migration Peter Sutherland; moreover, the EU was determined to launch the mission out of the Chapter VII of the UN Charter, almost for the first part in which the operation would be focused on «intelligence-gathering and "seizure" of ships» (Rettman 2015). The reason for this behavior by the Union was to activate the operation as soon as possible in order to curb the flows. Another reason was to avoid the likely contrariety by the United Nation Security Council that in this phase could have stopped the launch of the mission, for example the manifest opposition of Russia, which refused any military action in the Mediterranean capable of destabilizing the region, since the NATO campaign in Libya against Qaddafi in 2011 (Faleg 2015).

Following its way - but also starting to seek a mandate both from the UN and from the Libyan authorities in order to obtain a political coverage for the operation as the permission to "capture and destroy vessels used by the smugglers» (European Parliament 2015), on May $18^{\text {th }}$, the European Council with decision number 2015/778 launched the «European Union military operation in the Southern Central Mediterranean (EUNAVFOR MED)» (Coppens 2016). In particular, it defined how «a military crisis management operation contributing to the disruption of the business model of human smuggling and trafficking networks in the Southern Central Mediterranean (EUNAVFOR $M E D)$, achieved by undertaking systematic efforts to identify, capture and dispose of vessels and assets used or suspected of being used by smugglers or traffickers» (EU Council 2015d). The military footprint of the mission was clear, and this contributes to distinguishing this operation from others. The mandate of the mission was explained in article two of the Council decision, and it was composed of three different phases. In the first, the mission was supposed to «support the detection and monitoring of migration networks through information gathering and patrolling on the high seas». The second and third phases were the more critical, because the mission was supposed to conduct «boarding, search, seizure and diversion on the high seas of vessels suspected of being used for human smuggling or trafficking» and «in accordance with any applicable UN Security Council Resolution or consent by the coastal State concerned, conduct boarding, search, seizure and diversion, on the high seas or in the territorial and internal waters of that State, of vessels suspected of being used for human smuggling or trafficking» (second phase). In the third stage, the operation was supposed to take «all necessary measures against a vessel and related assets, including through disposing of them or rendering them inoperable, which are suspected of being used for human smuggling or 
trafficking, in the territory of that State», but only «in accordance with any applicable UN Security Council Resolution or consent by the coastal State concerned» (EU Council 2015). A phase-four was mentioned to terminate the operation as soon as all the targets would have been achieved The following articles of the decision, signed by the HR Federica Mogherini, established that the political control of the operation was put under the Council and the HR, and that «the Political and Security Committee shall exercise the political control and strategic direction of EUNAVFOR MED». Finally, the Operational Commander was defined in the person of the Rear Admiral Enrico Credendino by the Italian Navy; the HQ «shall be located in Rome» (Marrone and Nones 2016), and «the financial amount for the common costs of EUNAVFOR MED shall be EUR 11,82 million» for a period of no more than 12 months.

\section{The Operation Implemented: Original Shortcomings and New Commitments}

Based on this political coverage, the EUNAVFOR MED Operation was officially launched on 22 July 2015, by the EU Council with the decision 2015/ 972 (EC 2015e). On that occasion, HR Federica Mogherini recognized how this time the Union acted in a very "fast way, with unanimity and unity», and that the operation «is just one part of a bigger strategy to save lives» (Mogherini 2015).

The deployment of the units started in the aftermath of the official announcement, with 14 European Member States involved (Nielsen 2015): Belgium, Finland, France, Germany, Greece, Hungary, Italy, Lithuania, Luxembourg, the Netherlands, Slovenia, Spain, Sweden, and the UK, which expressed its cooperative will as stated by the Minister of State for Europe Mr. David Lidington, who recognized as «the UK supported the operation, and was contributing a ship, HMS Enterprise, and a Merlin helicopter» (Foreign \& Commonwealth Office 2015). Among the European navies, Italy was the principal contributor, with the aircraft carrier Cavour identified as the flagship, led by the force Commander of the operation the Italian Rear Admiral Andrea Gueglio, plus 8 other naval units and 12 air assets (EEAS 2015a). In its first phase, the operation focused on "surveillance and assessment of human smuggling and trafficking networks in the Southern Central Mediterranean» (EC 2015). This kind of reconnaissance action was needed due to the lack of information by the EU about how the illegal businesses of the smugglers worked in the basin, and represented the main activity for the European vessels during the summer.

The EUNAVFOR MED also conducted an important action of search- andrescue (SAR) in the Mediterranean, with 2186 migrants saved in its four months of activity (Deutsche Welle 2015). This commitment led to the change of the name of the operation: on September 24, during a visit at the HQ in Rome, the HR Federica Mogherini released a statement in which she «suggest to Member States that we change the name of our Operation: instead of calling it EUNAVFOR MED, I suggest we use the name Sophia. To honour the lives of 
the people we are saving, the lives of people we want to protect, and to pass the message to the world that fighting the smugglers and the criminal networks is a way of protecting human life» (Mogherini 2015). Indeed Sophia was the name of a little baby born on 24 August on board a German rescue ship of the EUNAVFOR MED forces (EEAS 2015b). The period between the end of summer and the beginning of autumn was important for the Operation that experienced a first relevant operative evolution. In fact, after the positive acknowledgments came at the informal meetings on 3 and 5 September from the Defense and Foreign Ministers of the EU, the EU Council decided on September 14 that the Political and Security Committee (PSC) would allow the mission to move on toward its second phase (EC 2015f).

This decision came the same day that the UNSC adopted Resolution 2240, authorizing the Member States for a period of one year «to inspect vessels on the high seas off the coast of Libya that they had reasonable grounds to suspect were being used for migrant smuggling or human trafficking from that country» (United Nations Security Council [UNSC] 2015). The PSC received quickly the Council advice, and on 28 September the EU Ambassadors decided that since October 7, 2015 the Operation Sophia would have been able to "board, search, seize and divert vessels suspected of being used for human smuggling or trafficking on the high seas» (EC 2015g). Since this moment, Sophia entered its crucial phase of activity, fighting the business of the smugglers. This was a step welcomed by the EU States with good reaction, even though some shadows started to surround the mission. Some perplexities came from the limit of the «high seas» as an area of operation of the mission: these were coherent with the original mandate, but the reality of the situation suggested that the core of the illegal activities of the traffickers was located closer to the Libyan shores.

As a consequence, a feeling of partial limits on the capacities of the operation emerged in the first report of the activity prepared by Admiral Credendino and submitted to the Council on 28 January 2016. The document refers to the period from 22 June to 31 December 2015, and represents a fair mirror of how the operation worked about migration in the Mediterranean. It starts with an overview of the migratory scenario, and noted that since September there had been important change, with a shift in the principal routes used by the migrants from the Central to the Eastern Mediterranean route: now the $83 \%$ of people arrived in Europe (771.237) had passed by the Eastern- Balkan route, and only $16 \%$ (154.725) used the Mediterranean route: an increase of $1664 \%$ with a reduction of $9 \%$ in the Mediterranean route in three year. With reference to these dates, the possible deterrence effect played by the Operation in order to discourage journeys across the sea was noted. Quickly the official document moved on the description of the activity of the operation during the Phase 1, lasted from June to 15 September, in which the units involved (in particular the Italian Air carrier Cavour, the HMS Enterprise and the FGS Schleswig-Holstein and FGS Werra) were committed to establishing a patrol cycle predominantly located in the south west of the operating area in what was determined the area of highest migration concentration». During these months, the main purpose of 
the operation was to «establish a presence and develop an understanding of the patterns of life within the area» and to «determining the background merchant and other maritime traffic, whilst determining the main hubs for migrant launch activity».

The operation could then successfully pass to phase $2 \mathrm{~A}$ (operation against smugglers on High Seas), with a deployment of a total of 16 vessels that arrested 46 suspected criminals and destroyed 67 boats. All data recognized how Libya was the center of $91 \%$ of the illegal activities, with an estimated amount of the trafficking business reaching €250-300 million. At this point, Credendino stated that he was «ready to move to phase $2 B$ in Libyan Territorial Waters, but there are a number of political and legal challenges that must be addressed». The "political and legal challenges" were (and still "are" today) the absence of a UNSCR of a local government authorization that could allow Sophia to operate more narrowly within the traffickers network on the Libyan territorial waters (TTW). This represents the key aspect of the entire mission, and the second part of the report is focused on the need for a further shift to phases $2 b$ and 3. In particular the Italian Admiral suggested how «in order to move to phase 2 in Libyan territorial waters, we need firstly an invitation from the GNA, as the sole legitimate Government of Libya», but he highlighted that "conducting operations under the conditions set out in an eventual Libyan invitation without any new applicable UNSCR would provide a weak legal basis to the operation». Here is an important recall to the international community that claim for a political coverage of the mission, in particular when he recognized as «the International Community is called upon to respond urgently to requests for assistance from the GNA for the implementation of the Libyan Political Agreement and to support in building the capacity of the Libyan Government of National Accord» (EEAS 2016b). Therefore, the main message that emerged from this first report is how the operation had positively answered by «providing $a$ deterrence effect in international waters, preventing smugglers from operating in International Waters», and it was ready to move forward to the next stages, even if implemented the next stages would need an international political effort that seemed to be not easy to foster. Finally, the impression that the operation was born with an original political sin started to reveal itself.

Of great importance seemed to be the second report of the mission activity, which covered almost all of 2016, from 1 January to 31 October. It was presented on 30 November to the European Council. The current year had been another cornerstone for the migration to Europe. Due to the EU- Turkey Agreement on April 2016, the total number of the arrivals in the continent dropped to 354.833: a significant reduction, especially if compared with almost 1 million of the previous year. This showed that a political and diplomatic initiative can influence the management of the phenomenon, and actually this step represented a crucial part of the EU global approach to migration. However, the general decrease of the arrivals masked a more complex reality. In fact 2016 also marked the (re)-emergence of the Central Mediterranean route, in particular for Italy, which registered a total of 181.436 arrivals: almost 30.000 migrants more than the previous year (Ministero dell' Interno 2017). This change was the comeback of 
the Central Mediterranean Route (CMR) as the «most intensively used pathway into Europe» (Jones 2016). Concerning the causes of this change, Operation Sophia highlighted the closure of the Easter Mediterranean Route (EMR) due to the EU-Turkey deal, but in particular to the increase of migrations from Africa, as proved by the ethnic composition of the migrants arriving in Europe. With the focus once again put on the Mediterranean, Sophia was observed with particular attention. During the first six months, the mission continued its duty, acting as a deterrence force, capturing 53 suspected criminals, destroying 269 boats and rescuing 29.317 migrants. The SAR activity was even more necessary due to the great number of organized travels by the smugglers during the summer favored by the meteorological variable. New criticism focused on the rapid inflow of migrants attempting to cross the Sea, so that the Operation was seen as a «pull-factor» for migration. The Commander categorically denied these allegations and argued that «the number of persons rescued by our assets accounts for only 13 percent of the total number of migrants rescued on the $C M R »$. Even if without any explicit accusation, but clearly in an ambiguous tone, the report added that 26 NGO maritime assets have been registered on the high seas on the CMR [...] that are ready to rescue migrants within the limit of, and sometimes inside, Libyan territorial waters». The high number of actors involved in the area caused confusion, and represented a potential source of incidents and concern. In this scenario the Operation Sophia could «act as a stabilizing factor in the Mediterranean», (EEAS 2016c). This was even more so because, together with the polemics, the Operation was also about to receive new commitments and a first renewal of its mandate. Carrying on with orders, on 23 May the EU Council - with the good advice of both the HR and the Presidency Council of the Libyan GNA Fayez Serraj - decided «to extend and amend EUNAVFORMED's mandate and add two further supporting tasks: capacity building and training of the Libyan Coastguard and Navy» to contribute to the «implementation of the UN arms embargo on the High Seas off the coast of Libya» (EC 2016a). These two new important tasks testified how the Union continued to believe in the Operation and its adaptability to a quick changing phenomenon. In particular, although this can be seen as a removal from the original mandate, the new commitments revealed an inclination - already shown by EUNAVFOR MED - to develop a stronger political collaboration with the Libyan authorities, which was seen as an essential point for the European strategy.

To pursue these new goals, on 20 June the Council announced the extension for another year (until 27 July 2017) of the Operation mandate (EC 2016b); in the meantime, on June 14th the UNSC emanated the Resolution number 2292, that allowed the Operation to guarantee the UN embargo on Libya (EEAS 2016a), and on 30 August the PSC finally authorized the mission to start training the first group of personnel from the Libyan Coastal Guard (Political and Security Committee [PSC] 2016).

These new tasks, the second report of the activity of the operation ended with the clear consideration that «ENFM is only a small piece of the big puzzle that need to be looked at and is part of the Comprehensive approach, but it is 
necessary that all efforts are synchronized and coordinated»(EEAS 2016b). This statement by Credendino seemed very significant because it recognized how the mission could positively act in a specific and technical scope, but it needed a coherent political design, that until the end of November 2016 was mined by many different obstacles. In particular, the Commander referred to the impossibility of moving to phase $2 \mathrm{~B}$ and the funding coverage. In front of a significant increase of assignments, the new common budget was indeed $€ 6.7$ million, almost half the first budget. In order to match all the activities, a greater contribution was requested from any Member States participating in the operation - Italy contributed €69.799.938 million in 2016 - but this would have been subjected to a possible delay thus impacting the effectiveness of the Operation (Gilioli, 2017).

\section{6 -2017: Sophia in Dangerous Waters}

The anxieties related to the reduction of the financial coverage were only the tip of the iceberg. Even though the EU institutions seemed to reach a general consensus on the operation, the weeks before the renewal were characterized by new critics on the usefulness of such a naval mission, in particular by the United Kingdom, one of the key contributors (BBC 2016). The British concerns were collected in a report prepared by the MPs of the UK European Union Committee, entitled "Operation Sophia, the EU's naval mission in the Mediterranean: an impossible challenge» (UK European Union Committee 2016), presented at the House of Lords on 13 May 2016. The report analyzed all the aspects of the mission, and argued that «the Operation Sophia does not, and cannot, deliver its mandate. It responds to symptoms, not causes» (UK European Union Committee 2016).

First, the British MPs argued that «the intentions and objectives set out for Operation Sophia exceed what can realistically be achieved. A mission acting only on the high seas is not able to disrupt smuggling networks, which thrive on the political and security vacuum in Libya, and extend through Africa» (UK European Union Committee 2016). The result of this was «a limited operation with limited objectives» (UK European Union Committee 2016). In their eyes, Sophia should remain a toll and could not be the solution for the European migration, because «it cannot be considered in isolation from the global phenomenon of mass migration, the implications of which go far beyond the scope of this brief report on Operation Sophia» (UK European Union Committee 2016). Recognizing this objective limit was a mistake that would expose the mission itself to various accusations. In particular, with the Operation unable to move to the second and third phases, and thus confined to operate in the high seas, the "search and rescue activity would act as a magnet to migrants and ease the task of smugglers, who would only need their vessels to reach the high seas» and it «does not in any meaningful way deter the flow of migrants, disrupt the smugglers' networks, or impede the business of people smuggling on the central Mediterranean route» (UK European Union Committee 2016). 
The report suggested that the EU and its Members draw attention to the causes of the flows in their global dimension, and affirmed that «the current migration crisis is exacerbated by conflicts in the Middle East and the security vacuum in Libya, but it is also part of a wider phenomenon of mass migration from the developing to the developed world. This will remain a challenge for the developed world in the long term» (UK European Union Committee 2016). Finally, the MPs did not ask for a UK retreat from the mission or to stop the entire operation, but they did «recommend that the Member States should review and renew the mandate in summer 2016», assuming a more balanced opinion of the real possibilities of the mission. They also suggested developing other channels - for instance with broader political contacts with the Libyan authorities in order to address the illegal business of the traffickers (European Union Committee 2016).

All the shadows that emerged in 2016 did not disappear in 2017. In the first part of the year the mission continued to be committed to its tasks, in particular providing high training levels to the a total of 89 new officials (EEAS 2017). At the test of the first renewal approval, the perplexities however raised again, counting on the fact that the operation was still locked on phase $2 \mathrm{~A}$ in high waters. Now the doubts were perceived also within EU institutions and confirmed by the circulation of a report by the EEAS for the PSC on 15 May, which aimed to offer a strategic review of the mission. The starting point was the verification that «due to continued political and legal challenges preventing the operation from entering Libyan sovereign waters and thereby transiting to subsequent phases of its mandate, the operation has been constrained to continue operating on the high seas» (EEAS 2017). Despite the consideration that «Op. Sophia is likely not to be able to transition to Phase $2 b$ in the foreseeable future» (EEAS 2017) the report praised the good results achieved until that moment and suggested a possible future scenario for the mission. In the document the option to stop the activities is categorically rejected, because "the closure of Op Sophia would incur a reputational risk in a context where more rather than less is expected from the EU and containment of the security challenges facing the EU would not be addressed» (EEAS 2017). On the contrary, it was suggested to use «Op Sophia as a lever to foster further Libyan ownership», and in particular to "continue the operation as it is, and prolong its mandate until 31 December 2018 to enhance 1) focus on maritime security operations on the high seas 2) information sharing with law enforcement agencies 3) cooperation with the Libyan authorities through training and information sharing and 4) support the establishment of a monitoring mechanism» (EEAS 2017).

Nevertheless, on 12 July, just some days before the end of the mandate and the start of the discussions within the EU Council in order to prolong the mission, a new report edited by the British EUC entitled «Operation Sophia: a failed mission» expressed a harsher opinion (UK European Union Committee 2017).

The first part of the document is candid in outlining how "Operation Sophia has failed to achieve its objective of "contributing to the disruption of the business model of human smuggling and trafficking networks in the Southern 
Central Mediterranean» and that - despite the fact that the mission faced «an impossible challenge» - "a naval mission is the wrong tool to tackle irregular migration which begins onshore: once the boats have set sail, it is too late to undermine the business of people smuggling» (UK European Union Committee 2017). The only positive element of the operation was its humanitarian activity at sea. However, even this commitment could be accomplished only «using more suitable vessels than the high-end air and naval assets of Operation Sophia» (UK European Union Committee 2016). At the end the MPs concluded that "Operation Sophia is unlikely to move into either Phase $2 B$ or 3 in the short term. We therefore see little reason to renew the mandate of the mission in its current form beyond 2017» (House of Lords 2017). However, on the eve of the talks about the future of the operation, other states announced an increasing contribution to the mission. This was the case of Spain, which on 22 of June 2017 announced that it would assume the command of the naval operations for the period between September and December, replacing the Italian guide. The Government of Madrid was the only among the 25 Member States involved in the operation to answer positively to the Italian claim of sharing the operative responsibilities of the mission. Spain - in 2016 one of the main contributors with 254 troops and a financial contribution of $€ 67$ million (Urra 2017, BBC 2017) - was directly involved in the migration scenario with reference to the Western Mediterranean route (WMR), through which in the summer 2017 the number of migrants tripled compared to the previous year (IOM 2017). Concerning the reasons that pushed Rome to ask for help with leading the operation - even if the general Command of the operation would continue to be under Admiral Credendino's control - some diplomatic sources argued that Operation Sophia was becoming not so effective at stemming the migration flows, and that in the first six months of 2017, especially between May and June, over 23.500 migrants were registered. The Italian choice seemed to be coherent with the new strategy launched by the Interior Minister Minniti since February, with the signing of the Malta Memorandum with the Libyan authorities, aimed at supporting the training of the Libyan Coastguard and achieving a political agreement on the migratory management from Northern Africa country (UNHCR 2018, Toaldo 2017).

Finally, the EU Council on 25 July - embracing the previous decision taken by the PSC on 4 July - decided to «extend the mandate of the EUNAVFOR MED Operation Sophia until 31 December 2018», adding to its mandate other tasks, such as «set up a monitoring mechanism of trainees of the Libyan Coastguard; conduct new surveillance activities and gather information on illegal trafficking of oil exports from Libya in accordance with UNSCR 2146 (2014) and 2362 (2017)»; and finally «enhance the possibilities for sharing information on human trafficking with member states' law enforcement agencies, FRONTEX and EUROPOL» (EC 2017). Even if the reports related to activities of the operation in the last part of 2016 and for all 2017 are still classified, the unanimous decision - thus overcoming the British concerns (Morgan 2017) taken by the Council was an important achievement for the operation, able to survive once again against its limits and critics, but also to confirm that the 
Union would go on believing in the role played by its naval mission as an important part of its comprehensive approach to Mediterranean migrations.

\section{Conclusions: A Mission with an Original Sin}

The reconstruction of the genesis and following activities during these three years of Operation Sophia seems useful to develop some general reflections on the contribution of a Europe-led naval military mission to manage migratory flows.

As shown by figures, since its first phase EUNAVFORMED has contributed to curbing the most tragic effects of the emergency, rescuing more than 36.000 migrants at sea and helping to better understand how the illegal business of the traffickers works in the basin (Micallesin 2017). The effectiveness and the readiness showed by Sophia represented a useful tool for achieving better control of the migratory situation in the Mediterranean.

However, the SAR activity also inspired severe criticisms from those who argue that the operation did not achieve its original mandate and thus represents another factor of instability in an already chaotic scenario. Some of these accusations seem to be true, since the mission is still only in its second phase after three years. Notwithstanding, this appears to be the result of an original sin which has characterized the operation since its theorization. In fact, Operation Sophia had been established as an emergency answer, in a period when the EU was threatened by a phenomenon towards which it was far away to set a comprehensive strategy and in front of which the EU Member States were deeply divided.

Thus from the beginning the weakness of the operation was clear and such was the absence of political coverage - shared both among the Union and with the origin and transit States - that could allow the operation to fully accomplish its mandate in all its scheduled phases. In this light, the decision of an established naval mission represented a shortcoming result, fostered by the impossibility of rapidly reaching political cooperation between the two shores on the Mediterranean on migration, but without the essential background it answered within its capabilities only to the symptoms and not to the causes of the flows.

After highlighting the limits of this operational military instrument at this point, a question can be asked if it is still useful to maintain a military operation due to the recent reduction of the flows to Europe and in the Central Mediterranean route.

Italy in particular, during the period between the second part of 2017 and until the beginning of the spring 2018, registered a huge drop in the arrivals, with a final reduction in 2017 of almost $27 \%$ of incoming migrants in comparison with 2016. In the first months of 2018, this decrease was confirmed and on 16 February this was of $22.73 \%$ compared to 2016 and of $49.33 \%$ compared to 2017 has been recorded (Ministero dell'Interno 2018). This new trend also questions whether this reduction is the result of the Sophia presence in the 
waters of the basin. The evident drop of the arrivals seems to be the result of the bilateral rapprochement between the Italian government and the Libyan authorities - sponsored by the EU institutions - rather than a direct effect of the naval operation. Once again, the political action shows more evident effects than a single initiative. However, in the current situation, which is no longer characterized as a critical emergency, there could emerge a more fair interpretation of the naval mission.

In this sense, the EU has come and in the future should continue to consider the operation as a key part of its migration strategy, but not as a decisive tool. Rather, it should be seen as a useful piece of a complex political puzzle (Johansen 2017). This seems to be the path followed by the Union, as testified by the new amendments to the mandate in the last two years. These were not an afterthought of the original mandate of the operation, but a needed adjustment based on experience and better knowledge of a phenomenon that will still interest the Euro-Mediterranean region in the long-run, and for which not just one tool and not the military one alone - may be decisive without a political framework in which to act.

\section{Acknowledgments}

Dr. Gian Lorenzo Zichi gratefully acknowledges Sardinia Regional Government for the financial support of his PhD scholarship (P.O.R. Sardegna F.S.E. Operational Programme of the Autonomous Region of Sardinia, European Social Fund 2007-2013 - Axis IV Human Resources, Objective 1.3, Line of Activity 1.3.1.)

\section{References}

Allied Marittime Command NATO (2016) Operation Sea Guardian. Retrieved from ht tps://www.mc.nato.int/missions/operation-sea-guardian.aspx. [Accessed 26 February 2018].

Bajekal, N (2014) Boat Migrants Risk It All for New Life in Europe. The Time. Retrieved from http://time.com/3543082/italy-navy-mare-nostrum-migrants/. [Accessed 26 February 2018].

BBC News (2017) Migrant crisis: Spain arrivals triple compared with 2016. Retrieved from http://www.bbc.co.uk/news/world-europe-40895571. [Accessed 26 February 2018].

BBC News (2016) EU mission 'Failing' to Disrupt People-Smuggling from Libya. Retrieved from http://www.bbc.co.uk/news/world-europe-36283316. [Accessed 26 February 2018].

Chalabi M (2013) World's Deadliest Migration Routes. The Guardian. Retrieved from https://www.theguardian.com/news/datablog/2013/oct/03/migration-routes-migrantsboat-italian-lampedusa. [Accessed 26 February 2018].

Chase J (2018) Refugee Numbers in Germany Dropped Dramatically in 2017. Retrieved from http://www.dw.com/en/refugee-numbers-in-germany-dropped-dramaticallyin-2017/a-42162223. [Accessed 16 January 2018]. 
Chope C (2013) The Arrival of Mixed Migratory Flows to Italian Coastal Areas. Report - Committee on Migration, Refugees and Displaced Persons, Council of Europe. Retrieved from https://bit.ly/2HxgRWo. [Accessed 26 February 2018].

Coppens J (2016) Interception of migrant boats at sea, 205, in Violeta Moreno-Lax, in E Papastavridis (ed) Boat Refugees' and Migrants at Sea: A Comprehensive Approach: Integrating Maritime Security with Human Rights. Leiden and Boston: Brill Nijhoff.

Crawley H, Düvell F, Jones K, McMahon S, Sigona N, (2018) Unravelling Europe's 'Migration Crisis': Journeys Over Land and Sea, 140. Bristol: Policy Press,.

Deutsche Welle (2015) EU Announces Plan to Step Up Anti-Smuggling Operations in Mediterranean. Retrieved from http://www.dw.com/en/eu-announces-plan-to-stepup-anti-smuggling-operations-in-mediterranean/a-18747206. [Accessed 26 February 2018].

Dobrescu M, Schumacher T, Stavridis S (2017) Southern Europe: Portugal, Spain, Italy, Malta, Greece, Cyprus in A Hadfield, I Manners, GR Whitman, (eds) Foreign Policies of EU Member States: Continuity and Europeanisation, 93. London New York: Routledge.

EEAS (2015a) European Union Naval Force - Mediterranean. Retrieved from https:// bit.ly/2HuyC8F. [Accessed 26 February 2018].

EEAS (2015b) Remarks of the High Representative Federica Mogherini at the EUNAVFOR MED's Operational Headquarter in Rome. Retrieved from https://eeas.europa.eu/headquarters/headquarters-homepage/5943/remarks-of-thehigh-representative-federica-mogherini-at-the-eunavfor-meds-operationalheadquarter-in-rome-september-24-2015_en. [Accessed 26 February 2018].

EEAS (2016a) Statement by the HR/VP Federica Mogherini on the adoption of Resolution 2292 by the UN Security Council. Retrieved from https://eeas.europa. eu/headquarters/headquarters-homepage/4993_en. [Accessed 26 Febryary 2018].

EEAS (2016b) EUNAVFOR MED Op SOPHIA - Six Monthly Report 22 June - 31 December 2015. Retrieved from https://bit.ly/1TnGGsC. [Accessed 26 February 2018].

EEAS (2016c) EUNAVFOR MED Op SOPHIA - Six Monthly Report 1 January - 31 October 2016. Retrieved from http://statewatch.org/news/2016/dec/eu-councileunavformed-jan-oct-2016-report-restricted.pdf. [Accessed 26 February 2018].

EEAS (2017) EUNAVFOR Med Operation Sophia: HRVP Mogherini attends graduation ceremony of first training package of Libyan Navy Coastguard and Libyan Navy. Retrieved from https://bit.ly/2HxBj9o. [Accessed 26 February 2018].

EEAS (2017) Strategic Review on EUBAM Libya, EUNAVFOR MED Op Sophia \& EU Liaison and Planning Cell. Retrieved from https://bit.ly/2qqZejQ. [Accessed 26 February 2018].

European Commission (2015) European Agenda on Migration. Retrieved from https:// bit.ly/2nr4ctX. [Accessed 16 January 2018].

European Commission (2015) Joint Foreign and Home Affairs Council: Ten Point Action Plan on Migration. Retrieved from https://bit.ly/2HipWVj. [Accessed 16 January 2018].

European Commission (2015) A European Response to Migration: Showing solidarity and sharing responsibility by Dimitris Avramopoulos. Retrieved from http://euro pa.eu/rapid/press-release_SPEECH-15-5498_en.htm. [Accessed 26 February 2018].

European Council (2016a) Council Conclusions on EUNAVFOR MED Operation Sophia. (23 May 2016). Retrieved from https://bit.ly/2HjQrtj. [Accessed 26 February 2018].

European Council (2016b) EUNAVFOR MED Operation Sophia: Mandate Extended By One Year, Two New Tasks Added. Retrieved from https://bit.ly/2ioU6vw. 
[Accessed 26 February 2018].

European Council, (2015a) Council Conclusions on the EU Regional Strategy for Syria and Iraq as well as the ISIL/Da'esh threat. Retrieved from http://www.Con silium.europa.eu/en/press/press-releases/2015/03/16/council-conclusions-eu-regi onal-strategy-for-syria-and-iraq-as-well-as-the-isil-daesh-threat/. [Accessed 26 February 2018].

European Council (2015b) Council launches EU naval operation to disrupt human smugglers and traffickers in the Mediterranean. Retrieved from https://bit.ly/2q uuLAu. [Accessed 26 February 2018].

European Council (2015c) Special meeting of the European Council, 23 April 2015 statement. Retrieved from http://www.consilium.europa.eu/en/press/press-relea ses/2015/04/23/special-euco-statement/. [Accessed 26 February 2018].

European Council (2015d) COUNCIL DECISION (CFSP) 2015/778 of 18 May 2015 on a European Union military operation in the Southern Central Mediterranean (EUNAVFOR MED). Retrieved from https://bit.ly/2GXr6SO. [Accessed 16 January 2018].

European Council (2015e) COUNCIL DECISION (CFSP) 2015/972 of 22 June 2015 launching the European Union military operation in the southern Central Mediterranean (EUNAVFOR MED). Retrieved from https://bit.ly/1R6s3J6. [Accessed 26 February 2018].

European Council (2015f) EUNAVFOR Med: EU agrees to start the active phase of the operation against human smugglers and to rename it "Operation Sophia". Retrieved from https://bit.ly/2GWyJJ3. [Accessed 26 February 2018].

European Council (2015g) EUNAVFOR Med: Council adopts a positive assessment on the conditions to move to the first step of phase 2 on the high seas. Retrieved from https://bit.ly/2HwumFz. [Accessed 26 February 2018].

European Council, (2017) EUNAVFOR MED Operation Sophia: mandate extended until 31 December 2018. Retrieved from https://bit.ly/2Ho6o1E. [Accessed 26 February 2018].

European Parliament (2015) EU Mounts New Maritime Operation to Tackle Mediterranean People Traffickers. Retrieved from https://bit.ly/2JIIE6U. [Accessed 26 February 2018].

European Union Committee (2016) Operation Sophia, the EU's Naval Mission in the Mediterranean: An Impossible Challenge. House of Lords. $14^{\text {th }}$ Report of Session 2015-16. HL Paper 144. Retrieved from https://bit.ly/2IQzdAW. [Accessed 26 February 2018].

Faath S, Mattes H (2014) Political Conflicts and migration in the MENA states, 182, in M Bommes, H Fassmann, W Sievers, (eds) Migration from the Middle East and North Africa to Europe: past developments, Current Status and Future Potentials. Amsterdam: Amsterdam University Press.

Faleg G (2015) EU Naval Force EUNAVFOR MED sets sail in troubled waters, in G Faleg, S Blockmans (eds) CEPS Commentary 26 June 2015. Retrieved from https://www.files.ethz.ch/isn/192082/CEPS\%20Commentary\%20EUNAVFOR\% 20G\%20Faleg\%20S\%20Blockmans.pdf. [Accessed 26 February 2018].

Mogherini F (2015) Our Efforts to Save Migrants: The Naval Operation, and all the Rest. Retrieved from http://www.federicamogherini.net/our-efforts-to-save-migra nts-the-naval-operation-and-all-the-rest/?lang=en. [Accessed 26 February 2018].

Foreign \& Commonwealth Office (2015) Written Ministerial Statement: Foreign Affairs Council and General Affairs Council 22 - 23rd June. Retrieved from https:// www.gov.uk/government/speeches/written-ministerial-statement-foreign-affairscouncil-and-general-affairs-council-22-23rd-june. [Accessed 16 January 2018]. 
FRONTEX (2014) Joint Operation Triton (Italy). Retrieved from https://bit.ly/2mo TLcA. [Accessed 26 February 2018].

FRONTEX (2018) Migratory Routes Map (2018). Retrieved from https://bit.ly/1FZM UYU. [Accessed 16 January 2018].

Gauci J, Mallia P (2016) The Migrant Smuggling Protocol and the Need for a Multifaceted Approach: Inter-sectionality and Multiactor Cooperation. 140, in V Moreno -Lax, E Papastavridis 'Boat Refugees' and Migrants at Sea: A Comprehensive Approach: integrating maritime security with human rights. Boston: Brill Nijhoff.

Gilioli F (2017) Note su atti dell'Unione Europea, Nota N. 113 L'Operazione EUNAVFOR MED SOPHIA. Servizio Studi. Servizio delle Commissioni. Senato della Repubblica Italiana. Retrieved from https://bit.ly/2Hv72YS. [Accessed 26 February 2018].

Grant H, Domokol J (2011) UK Failing to Share Burden of Migration Crisis, Says Southern Europe. The Guardian. Retrieved from https://bit.ly/2Hnpvcx. [Accessed 16 January 2018].

Hammond GT (2015) The Mediterranean Migration Crisis. Foreign Policy Journal. Retrieved from https://bit.ly/2Hir2Ap. [Accessed 26 February 2018].

Hermanin C (2017) Immigration Policy in Italy: Problems and Perspectives. (2017). IAI Working Papers 17 35, 7. ISSN 2280-4331 | ISBN 978-88-9368-064-6. Retrieved from http://www.iai.it/sites/default/files/iaiwp1735.pdf. [Accessed 16 January 2018].

House of Lords, European Union Committee (2017) Operation Sophia: a Failed Mission. HL Paper 5. Retrieved from https://bit.ly/2uxPfMa. [Accessed 26 February 2018].

International Organization on Migration (IOM) (2017) Mediterranean Migrant Arrivals Top 363,348 in 2016; Deaths at Sea: 5,079. Retrieved from https:// www.iom.int/news/mediterranean-migrant-arrivals-top-363348-2016-deaths-sea5079. [Accessed 16 January 2018].

International Organization on Migration (IOM) (2017) Mediterranean Migrant Arrivals Reach 165,409 in 2017 with Major Uptick in Western Route. Retrieved from https:// www.iom.int/news/mediterranean-migrant-arrivals-reach-165409-2017-major-up tick-western-route. [Accessed 26 February 2018].

International Organization on Migration (IOM) (2015) Migrant Arrivals by Sea in Italy Top 170,000 in 2014. Retrieved from https://www.iom.int/news/migrantarrivals-sea-italy-top-170000-2014. [Accessed 26 February 2018].

International Organization on Migration (IOM) (2018) Missing Migrant Project. Fatalities by month. Retrieved from https://bit.ly/2j3e5PV. [Accessed 26 February 2018].

Johansen IA (2017) Assessing the European Union's Strategic Capacity: The Case of EUNAVFOR MED Operation Sophia. European Security Journal, Vol. 26, Issue 4, 507-526. Retrieved from https://doi.org/10.1080/09662839.2017.1361933. [Accessed 16 January 2018].

Jones C (2016) The EU's Military Mission against Mediterranean Migration: What "Deterrent Effect"? Retrieved from http://www.statewatch.org/analyses/no-302operation-sophia-deterrent-effect.pdf. [Accessed 16 January 2018].

Kirchgaessner S, Bonomolo A (2015) UN says 800 Migrants Dead in Boat Disaster as Italy Launches Rescue of Two More Vessels. Retrieved from https://www.theguar dian.com/world/2015/apr/20/italy-pm-matteo-renzi-migrant-shipwreck-crisis-sre brenica-massacre. [Accessed 16 January 2018].

Militare M (2014) Mare Nostrum Operation. Retrieved from https://bit.ly/1zNLzkg. [Accessed 26 February 2018].

Marrone A, Nones M (2016) Italy and the Security in the Mediterranean. 121. IAI 
Research Papers. Edizioni Nuova Cultura. Roma. 2016.

Micalessin G (2017) La missione Ue "Sophia" è ferma al palo. Retrieved from https:// bit.ly/2tjZGlO. [Accessed 26 February 2018].

Ministero dell'Interno (2018) Cruscotto Statistico 16 Febbraio 2018. Retrieved from https://bit.ly/2GUEDhN. [Accessed 26 February 2018].

Ministero dell'Interno (2017) Cruscotto Statistico Giornaliero. Retrieved from http:// www.libertaciviliimmigrazione.dlci.interno.gov.it/sites/default/files/allegati/cruscotto _statistico_giornaliero_31_gennaio_2017_1.pdf. [Accessed 26 February 2018].

Ministero dell'Interno (2014) Si conclude 'Mare Nostrum', al via 'Triton'. Retrieved from https://bit.ly/2Hv8Hha. [Accessed 26 February 2018].

Morgan S (2017) EU Naval Mission Granted More Time and Objectives. Euractiv. Retrieved from https://www.euractiv.com/section/global-europe/news/eu-navalmission-granted-more-time-and-objectives/. [Accessed 26 February 2018].

Nielsen N (2015) EU Navies Take Up Position in Mediterranean. Euobserver. Retrieved from https://euobserver.com/foreign/129229. [Accessed 26 February 2018].

Nilsson M (2017) European Union (EU), 79. In D Silander, D Wallace, J Janzekovic (eds) International Organizations and The Rise of ISIL: Global Responses to Human security threats. Routledge, London and New York.

Park J (2015) Europe's Migration Crisis. The Council on Foreign Relations. Retrieved from https://www.cfr.org/backgrounder/europes-migration-crisis. [Accessed 16 January 2018].

Political and Security Committee (2016) Decision (CFSP) 2016/1637 of 6 September 2016. Retrieved from http://eur-lex.europa.eu/eli/dec/2016/1637/oj. [Accessed 26 February 2018].

Rettman A (2015) EU Preparing to Start Migrant Operation before UN Approval. EuObserver. Retrieved from https://euobserver.com/justice/128719. [Accessed 26 February 2018].

Riddervold M (2018) The Maritime Turn in EU Foreign and Security Policies: Aims, Actors and Security Policies. Aims, Actors and Mechanisms of Integration. 6768. Cham, Switzerland: Palgrave Macmillan.

Ritter J, Rhomberg M, Barlai M, Fähnrich B, Griessler C, (2017) Introduction European Perspectives and National Discourses on the Migrant Crisis, 15, in M Barlai B Fähnrich, C Griessler, M Rhomberg, (eds) The Migrant Crisis: European Perspectives and National Discourses. Zürich: Lit Verlag.

Toaldo M (2017) The EU Deal with Libya on Migration: A Question of Fairness and Effectiveness. European Council on Foreign Relations. Retrieved from http:// www.ecfr.eu/article/commentary_the_eu_deal_with_libya_on_migration_a_ques tion_of_fairness_a. [Accessed 26 February 2018].

UNHCR (2018) Europe Monthly Report. Retrieved from https://bit.ly/2EI5Tu3. [Accessed 26 February 2018].

UNHCR (2015a) Over one million sea arrivals reach Europe in 2015. Retrieved from http://www.unhcr.org/afr/news/latest/2015/12/5683d0b56/million-sea-arrivalsreach-europe-2015.html [Accessed 16 January 2018].

UNHCR (2015b) The Sea Route to Europe: The Mediterranean Passage in the Age of Refugees, 13. Retrieved from http://www.unhcr.org/5592bd059.pdf. [Accessed 26 February 2018].

UNHCR (2014) UNHCR concerned Over Ending of Rescue Operation in the Mediterranean. Retrieved from https://bit.ly/2GYniVy. [Accessed 26 February 2018].

UNHCR (2013) UNHCR Highlights Dangers facing Syrians in Transit, Urges Countries to Keep Borders Open. Retrieved from https://bit.ly/2HgPVfT. [Accessed 26 
February 2018].

United Nations Security Council (2015) Adopting Resolution 2240 (2015), Security Council Authorizes Member States to Intercept Vessels off Libyan Coast Suspected of Migrant Smuggling. Retrieved from https://bit.ly/2HiPMso. [Accessed 26 February 2018].

Urra S (2017) Spain to Head EU Mission against Human Smuggling in Mediterranean. El Pais. Retrieved from https://bit.ly/2IOA2u8. [Accessed 26 February 2018].

Warnes S (2014) Migrants Crossing the Mediterranean: Key Numbers. The Guardian. Retrieved from https://bit.ly/2JIsZVl. [Accessed 16 January 2018]. 